\section{Prospects brighten for France's Soleil synchrotron facility}

[PARIS] French plans to build a new national synchrotron are likely to be approved after next month's regional elections, according to several sources in the synchrotron user community. Plans for the $2.15 \mathrm{GeV}$ Soleil synchrotron, which will cost FFr1 billion (US\$ 160 million), were suspended last year by the Socialist government.

Yves Farge, a former ministerial adviser and currently head of research at Pechiney, is resigning to become head of a joint commission between the French Atomic Energy Commission (CEA), the Centre National de la Recherche (CNRS) and the ministry to consider synchrotron radiation in France. Eventually, it is believed, he will head the Soleil project.

Soleil is intended to replace the ageing Lure facilities near Paris, of which Farge was the founder, which has $800 \mathrm{MeV}$ and 1.85 $\mathrm{GeV}$ synchrotrons.

The new synchrotron facility has received the backing of Catherine Bréchignac, the director general of CNRS, and Yannick d'Escatha, director general of CEA. But to the dismay of many scientists, the scheme was frozen in November by Claude Allègre, the minister for national education, research and technology, as part of a review of spending on 'big science' (see Nature 390, 212; 1997).

Allègre said at the time that large facilities could only be run economically if they were in operation for 24 hours a day, as was the case for international facilities but not national ones. The creation of the latter, he declared would "become the exception". For this reason, he said, the Soleil project would be made "dormant", although not cancelled as such.

But many scientists criticized the decision as being out of touch with the "huge demand" in many research communities. They pointed out that the Soleil project design explicitly specifies that it will operate 24 hours a day, and that synchrotrons are not big equipment used by a few, but a shared tool used by many disciplines.

The underlying reasons for the delay seem to be political, however. Allègre is said to have been keen to avoid taking a decision on the location of the synchrotron -42 towns have applied to host the facility until after next month's regional elections.

According to several scientists, a decision to approve Soleil will be announced at that point. Recent statements by Allègre have suggested that his own preference for the location of the machine is in the Paris region, where existing facilities are concentrated.

Declan Butler

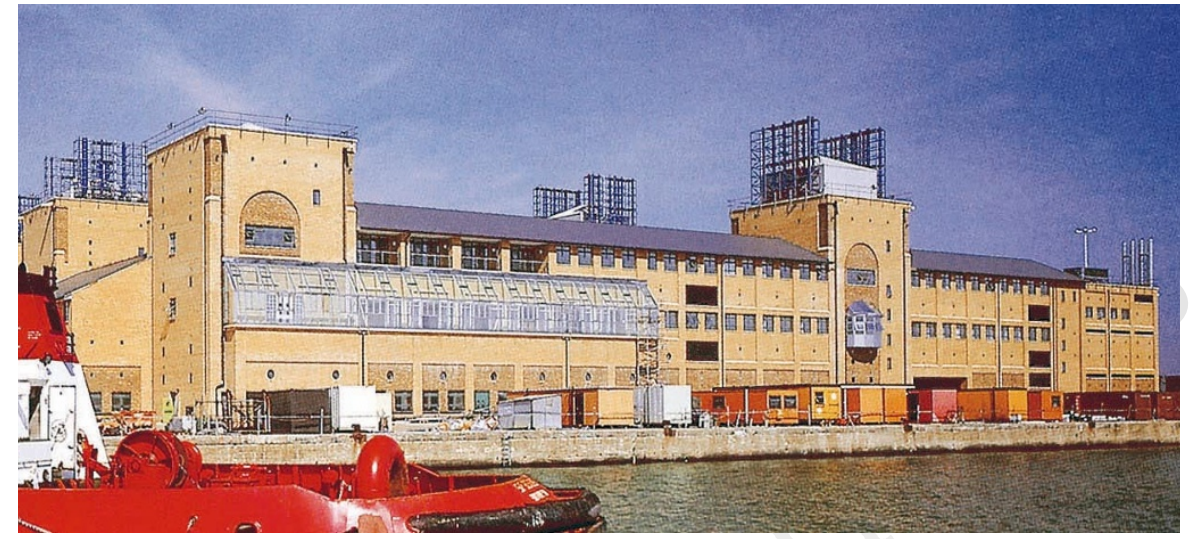

Hot water: Southampton Oceanography Centre was completed two years late, and over budget.

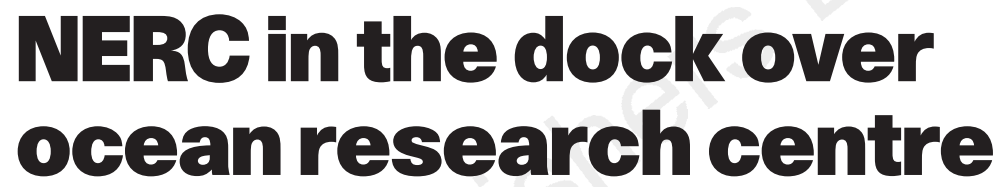

[LONDON] Britain's Natural Environment Research Council (NERC) has been accused of "parasitizing" taxpayers during the construction of a $£ 49$-million (US\$80-million) oceanography research centre off the south coast of England. The centre was completed nearly two years behind schedule, and was $£ 2.7$ million over budget.

At a public hearing last week, members of the House of Commons' Public Accounts Committee described the construction of the Southampton Oceanography Centre as a "sorry tale" of scientists with little business experience losing control of the construction of a multi-million-pound facility.

One committee member, Charles Wardle (Conservative MP for Bexhill and Battle), said that, although he respected the council's scientific expertise, he felt it had used public funds unnecessarily and allowed itself in turn to be "parasitized" by the architects and builders. Another member, Phil Hope (Labour, Corby), castigated council members for "wasting taxpayers' money" and having "their heads in the clouds" when important decisions needed to be taken.

In response, John Krebs, NERC's chief executive, told the committee that the council had learnt its lessons from the affair, and that, since he had taken over in 1994, new guidelines had been adopted and past mistakes would not be repeated. He added that despite the difficult start, the centre had rapidly become a "world class facility".

Andrew Love (Labour, Edmonton) asked how the centre could be described as a "world class" facility when it lacked a proper lecture theatre or auditorium. Krebs responded by saying that a measure of the centre's quality was its ability to attract "superstar" scientists from other countries, such as the United States, despite offering lower salaries.

The committee had summoned NERC officials for questioning following a government audit report last month on the centre's construction. The facility was designed to provide research and teaching in oceanography, as well as acting as a berth for research vessels.

The report criticized the council for not supervising the project properly. It revealed that the council failed to appoint an overall project manager, despite repeated advice. Sir John Knill, NERC's chairman at the time, jointly managed the project with the vicechancellor of the University of Southampton.

According to the report, the council allowed builders and architects to make changes to the project without consulting NERC, leading to increased costs. The architects' fees doubled to $£ 8.6$ million. The construction company Wimpey claims it is still

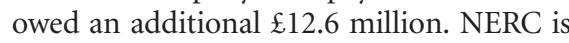
challenging the claim.

The report also states that the project had to be scaled down to meet these rising costs. Components of the original design — such as a conference centre and a facility to display the centre's research to the public - had to be omitted, it says, as NERC could not afford to build to the original specification.

But John Woods, who was NERC's director of marine sciences when the centre was constructed, denies this, describing the changes instead as a process of "continuous refinement".

Woods, who is now dean of the graduate school of the environment at Imperial College, London, says that heads of departments were first asked to write down their "dream list" of facilities. "They all knew that they wouldn't get what they wanted. But it was a starting point."

He argues that the conference room and public understanding centre were deliberately omitted as he felt they could be built with private finance. This would leave more of the public funds to be spent on 'scientific' facilities that would be potentially less attractive to a private donor.

EhsanMasood 